\title{
CEO gender, corporate risk-taking, and the efficiency of capital allocation
}

\section{DOI:}

10.1016/j.jcorpfin.2016.02.008

\section{Document Version}

Accepted author manuscript

Link to publication record in Manchester Research Explorer

\section{Citation for published version (APA):}

Faccio, M., Marchica, M., \& Mura, R. (2016). CEO gender, corporate risk-taking, and the efficiency of capital allocation. Journal of Corporate Finance, 39, 193-209. https://doi.org/10.1016/j.jcorpfin.2016.02.008

\section{Published in:}

Journal of Corporate Finance

\section{Citing this paper}

Please note that where the full-text provided on Manchester Research Explorer is the Author Accepted Manuscript or Proof version this may differ from the final Published version. If citing, it is advised that you check and use the publisher's definitive version.

\section{General rights}

Copyright and moral rights for the publications made accessible in the Research Explorer are retained by the authors and/or other copyright owners and it is a condition of accessing publications that users recognise and abide by the legal requirements associated with these rights.

\section{Takedown policy}

If you believe that this document breaches copyright please refer to the University of Manchester's Takedown Procedures [http://man.ac.uk/04Y6Bo] or contact uml.scholarlycommunications@manchester.ac.uk providing relevant details, so we can investigate your claim.

\section{OPEN ACCESS}




\title{
CEO Gender, Corporate Risk-Taking, and the Efficiency of Capital Allocation
}

\author{
Mara Faccio, ${ }^{\mathrm{a}}$ Maria-Teresa Marchica, ${ }^{\mathrm{b}}$ and Roberto Mura $^{\mathrm{c}}$
}

\begin{abstract}
We extend the literature on how managerial traits relate to corporate choices by documenting that firms run by female CEOs have lower leverage, less volatile earnings, and a higher chance of survival than otherwise similar firms run by male CEOs. Additionally, transitions from male to female CEOs (or vice-versa) are associated with economically and statistically significant reductions (increases) in corporate risk-taking. The results are robust to controlling for the endogenous matching between firms and CEOs using a variety of econometric techniques. We further document that this risk-avoidance behavior appears to lead to distortions in the capital allocation process. These results potentially have important macroeconomic implications for long-term economic growth.
\end{abstract}

\footnotetext{
a Krannert School of Management, Purdue University, 403 W. State Street, West Lafayette, IN 47907, U.S.A. Tel: 765-496-1951. E-mail: mfaccio@purdue.edu.

b Manchester Business School, University of Manchester, Crawford House, Booth Street East, Manchester, M13 9PL, U.K. Tel: +44-161-2750121. E-mail: maria.marchica@manchester.ac.uk.

c Manchester Business School, University of Manchester, Crawford House, Booth Street East, Manchester, M13 9PL, U.K. Tel: +44-161-2750120. E-mail: roberto.mura@manchester.ac.uk.

Acknowledgments: We thank an anonymous referee, Kevin Aretz, Kelley Bergsma, Paul Chaney, Dave Denis, Diane Denis, Art Durnev, Andrea Fracasso, Marc Goergen, Scott Hsu, Markku Kaustia, Seoyoung Kim, David Lesmond, Kai Li, Evgeny Lyandres, Ulrike Malmendier, Roni Michaely, Jeffry Netter (the Editor), Bill O’Brien, Eric Powers, Stefano Puddu, Michael Roberts, Jeremy Stein, Anjan Thakor, Jin Xu, Deniz Yavuz, Scott Yonker, Feng Zhang, and seminar participants at the Arison School of Business Interdisciplinary Center, Bristol University, Cardiff Business School, DePaul, Exeter Business School, INSEAD, Manchester Business School, Neuchatel University, Northwestern, Trento, Tulane, University of Florida, University of Southern California, University of Verona, Wayne State, the 2015 American Finance Association, the 2013 European Economic Association, the 2012 \& 2013 Financial Management Association Meetings, the 2014 Edinburgh Corporate Finance Conference and the Rotterdam Behavioral Finance Conference for comments and Hossein Khatami for research assistance. We also thank Bobby Foster from Bureau van Dijk and Mark Greenwood for technical assistance.
} 


\section{Introduction}

Among the Fortune 500 companies, the number of female CEOs reached its historic high in mid-2014. ${ }^{1}$ Despite that, with a headcount of only 24 (or $4.8 \%$ of the Fortune 500 firms), female CEOs remain an exception rather than a rule in corporate America. This "gender gap" in corporate leadership is not specific to large U.S. firms. In fact, according to a recent Wall Street Journal article, only 3\% of the largest 145 Scandinavian companies have a female CEO. ${ }^{2}$ Are the women who climb to the top of the corporate ladder close substitutes for male executives? Furthermore, are there differences in the decisions that female CEOs make after taking the corporate reins? And, are there implications for the efficiency of the capital allocation process?

In this paper, we investigate the relation between CEO gender, corporate risk-taking choices, and the efficiency of capital allocation. Using a large sample of privately-held and publicly-traded European companies from the Amadeus Top 250,000 database, 9.4\% of which are run by female CEOs, we first document first that female CEOs tend to associate with less risky firms. In the cross-section, firms run by female CEOs are less leveraged, have less volatile earnings, and are more likely to remain in operation than firms run by male CEOs. Additionally, in the time-series, transitions from male to female CEOs (or vice-versa) are associated with an economically and statistically significant decline (increase) in corporate risk-taking.

These findings are based on evidence from four different samples that are specifically selected to mitigate different endogeneity concerns. First, we compare firms run by female CEOs to a (propensity score) matched sample of peers run by male CEOs that are virtually indistinguishable in terms of observable characteristics. More specifically, peers are selected

\footnotetext{
${ }^{1}$ http://fortune.com/2014/06/03/number-of-fortune-500-women-ceos-reaches-historic-high/

${ }^{2}$ Wall Street Journal, May 21, 2014, “Even Scandinavia Has a CEO Gender Gap.”
} 
from the same country, industry, year, and public/private status, and then matched on a number of firm- and CEO-level characteristics. The basic propensity score results show that firms run by female CEOs take significantly less risk than otherwise similar firms run by male CEOs. Second, we employ a sample of firms experiencing a transition from male to female CEOs or vice-versa (henceforth referred to as "transition firms"). Focusing on transition firms allows us to compare the risk-taking of the same firms, as run by CEOs of different genders. Those tests indicate that CEO transitions are associated with changes in corporate risk-taking. In particular, transitions from male to female CEOs are associated with a reduction in corporate risk-taking. As the timing of CEO transitions is unlikely to be random, we supplement our analyses with a third sample. This consists of a propensity score matched sample of transition firms. In this analysis, we compare the change in risk-taking observed around transitions from male to female CEOs with the change in risk-taking of otherwise similar firms that are run by male CEOs during the entire sample period. The propensity score matching analysis of transition firms confirms a significant change in corporate risk-taking around CEO transitions, over and beyond what is observed (during the same period) among otherwise identical peers.

To investigate whether CEO gender still plays a role in financial and investment policies after explicitly accounting for self-selection due to unobservables, we employ a variation of the Heckman two-step approach: the treatment effects model. Our choice of an exogenous determinant of the propensity to select a female CEO is based on the familiarity of a firm's male directors with female CEOs. More specifically, our first stage instrumental variable is the fraction of firms with a female CEO and above-average risk-taking among all other firms in which the firm's male directors also serve as directors. We argue that it is unlikely that this familiarity, combined with above-average risk-taking (in other firms), will be correlated with 
outcomes (in particular, risk-avoidance) except through its effect on CEO gender. The results of the treatment effects model provide little support for the notion that the differences in corporate risk-taking observed between firms run by female and male CEOs are due to self-selection. Thus, the results appear to be consistent with CEO gender influencing corporate risk-taking.

To the extent that the documented differences in corporate risk-taking are driven by female CEOs imposing their preferences on corporate choices, the efficiency of the capital allocation process could be undermined. This would occur if female CEOs choose to forgo positive net present value investment opportunities. For example, female CEOs of high growth opportunity firms may be too risk-averse and fail to increase investment to fully capitalize on these opportunities. The second source of inefficiency is overinvestment. For example, for firms with poor investment opportunities, female CEOs may be reluctant to make divestitures and thus overinvest. ${ }^{3}$ To assess the efficiency of capital allocation, we borrow the basic idea from Wurgler (2000) and estimate the sensitivity of corporate investment to value added growth. We document that male CEOs invest more in industries that have better investment opportunities (as proxied by higher value added growth). However, investments of firms run by female CEOs are less sensitive to the quality of investment opportunities. Thus, female CEOs do not appear to allocate capital as efficiently as male CEOs. Similar conclusions are reached when we use marginal Q as the proxy for the quality of investment opportunities, as in Durnev, Morck and Yeung (2004).

Why does CEO gender help explain corporate risk-taking? Under perfect capital markets, managers should choose investments so as to maximize the market value of the firm. In this framework, neither the preferences or characteristics of managers nor those of the firm's owners

\footnotetext{
${ }^{3}$ We thank the Referee for highlighting these channels.
} 
play any role in the investment selection choice. Traditional finance theories propose agency and asymmetric information as ways in which a decision maker's preferences and characteristics may play a role in a firm's investment selection choice. Additional explanations include differences in risk-aversion between genders (Bertrand, 2011; Croson and Gneezy, 2009), overconfidence (Malmendier and Tate, 2005, 2008; and Malmendier et al., 2011), differences in incentives structures, differences in unemployment risk, as well as social norms related to the role of women in a given society (Akerlof and Kranton, 2000; Altonji and Blank, 1999; Booth and Nolen, 2012; Guiso et al., 2008). We discuss these mechanisms in Section 5.

This paper contributes to the literature investigating managerial traits and experiences that influence corporate decision making. Those studies include Bertrand and Schoar (2003), Malmendier and Tate (2005, 2008), Malmendier et al. (2011), Benmelech and Frydman (2015), Cronqvist et al. (2012), and Cain and McKeon (2014). We add to this literature by showing that CEO gender is also an important trait associated with differences in corporate choices.

Our paper also relates to earlier studies investigating how gender diversity correlates with differences in corporate decisions or outcomes. For example, Weber and Zulehner (2010) document that start-ups with female first hires display a higher likelihood of survival. Adams and Ferreira (2009) provide evidence that CEO turnover correlates more strongly with poor performance when the board of directors is more gender-diverse. Ahern and Dittmar (2012) document that the introduction of mandatory board member gender quotas led to an increase in acquisitions and performance deterioration in Norwegian publicly-traded firms. ${ }^{4}$ However, more recent studies by Adams and Ragunathan (2013) and Berger et al. (2014) document that banks

\footnotetext{
${ }^{4}$ Other work focusing on gender diversity in corporate boards includes Matsa and Miller (2013) and Levi et al. (2010 and 2014).
} 
with more women on their boards appear to take more risk (or at least not less risk) than banks with fewer female board members. In a recent study that employs a large sample of U.S. firms, Sila et al. (2016) document that the cross-sectional correlation between gender diversity and equity risk disappears once they account for the endogeneity of the gender selection choice.

However, there is little evidence investigating the relation between the gender of top corporate insiders and corporate choices. One exception is Huang and Kisgen (2013), who document that the propensity to make acquisitions is lower in companies with female CFOs. Their sample includes 19 female CEOs and 97 female CFOs. A second exception is a study of privately-owned (U.S.) firms by Cole (2013), who reports cross sectional evidence that femaleowned firms have lower leverage than male-owned firms. We add to this literature by documenting significant differences in the risk-taking profile of firms run by male and female CEOs.

The paper also contributes to the literature on the efficiency of capital allocation (Durnev et al., 2004, McLean et al., 2012, Morck eta al., 2011, Wurgler, 2000). Our paper is the first to provide evidence that differences in managerial traits, in particular gender, appear to have implications for the quality of the capital allocation process - - a fundamental underpinning of economic growth (Bagehot, 1873, Beck et al., 2000, Greenwood and Jovanovic, 1990, John et al., 2008).

The rest of the paper is organized as follows. Section 2 describes the data. Section 3 investigates the relation between CEO gender and corporate risk-taking. Section 4 investigates the implications for the quality of the capital allocation process. Section 5 discusses the 
economic reasons why CEO gender could impact risk-taking (including differences in risk aversion) and Section 6 concludes.

\section{Data}

Most of the data used in the paper are taken from Amadeus Top 250,000 and Worldscope. Amadeus is maintained by Bureau Van Dijk. From this database we gather information on the name of the CEO, ownership data, and accounting data for every European privately-held and publicly-traded company that satisfies a minimum size threshold. ${ }^{5}$ Disclosure requirements in Europe require private companies to publish annual information. Consequently, we are able to gather accounting, ownership and gender information for a very large set of firms. The quality of data in Amadeus Top 250,000 is discussed in detail in Faccio et al. (2011). We gather the data from the annual Amadeus Top 250,000 DVDs. ${ }^{6}$ Our sample period starts in 1999 (the first year for which we can gather ownership data from the DVDs) and ends in 2009 (the most recent year for which accounting and ownership data are available).

Later in the paper, we use Worldscope to gather stock price data and additional accounting data for publicly-traded firms. Those data are employed to estimate the marginal Q of each 3-digit SIC industry in each country, as described in detail in Appendix A.

\footnotetext{
${ }^{5}$ For France, Germany, Italy, Spain, and the United Kingdom, the database includes all companies that meet at least one of the following criteria: (1) revenues of at least $€ 15 \mathrm{~m},(2)$ total assets of at least $€ 30 \mathrm{~m}$, (3) at least 200 employees. For the other countries, the database includes all companies that meet at least one of the following criteria: (1) revenues of at least $€ 10 \mathrm{~m}$, (2) total assets of at least $€ 20 \mathrm{~m}$, (3) at least 150 employees.

${ }^{6}$ Amadeus removes firms from the database five years after they stop reporting financial data. These drawbacks are also discussed in Klapper et al. (2006) and Popov and Roosenboom (2009). In order to avoid potential survivorship bias, we collect data starting with the 2011 DVD and progressively move backward in time. By doing so, no firms are dropped from the sample.
} 
To select our sample, we start with the 41 countries covered in Amadeus. From these, we exclude countries that are not covered in Worldscope in the earlier years. Those are primarily Eastern European countries and smaller countries such as Liechtenstein and Monaco. This leaves us with a sample of 21 countries. Finally, we exclude the Czech Republic, Poland and the Russian Federation as, for these countries, the World Bank provides GDP deflators only starting in $1990 .{ }^{7}$ After these exclusions, the final sample used throughout the paper consists of the following 18 countries: Austria, Belgium, Denmark, Finland, France, Germany, Greece, Hungary, Ireland, Italy, Luxembourg, the Netherlands, Norway, Portugal, Spain, Sweden, Switzerland, and the United Kingdom.

\subsection{CEO Gender}

We identify the gender of a CEO primarily based on his/her first name, as reported in “Amadeus Top 250,000.” Since 2007, DVDs indicate the gender of the CEO. As a starting point, we use this information to classify CEOs from 2007 forward. We also use this information to classify those same individuals in the prior years. Prior to 2007, Amadeus does not indicate the gender of the CEO. However, at least in some instances, Amadeus reports a salutation. We use the salutation when it indisputably allows identifying the gender of the CEO. ${ }^{8}$ If these methods do not conclusively identify the CEO's gender, we employ country-specific internet-based sources to classify gender based on each individual's first name. ${ }^{9}$ Using country-specific sources is important to avoid misclassification. For example, Simone is used for women in France but for men in Italy. Finally, when we could not identify the gender from the names lists found on the

\footnotetext{
${ }^{7}$ The procedure employed to construct marginal Qs requires data starting from 1983 (see Appendix A).

${ }^{8}$ For instance, "Mr" versus "Ms/Mrs/Miss" or "Dr." versus "Dr. "." (more commonly used in Portugal).

${ }^{9}$ For instance, www.babynology.com, www.nordicnames.de, babynamesworld.parentsconnect.com, www.namepedia.org/en/firstname.
} 
web, we used OneSource, LinkedIn, Google and Facebook to further research the CEO and assess whether a specific name is a male or female name.

When we are unable to classify the gender of an individual, we drop the observation. Across all countries and all years, this procedure allows us to identify the gender of the CEO in 338,397 firm-year observations. As shown in Table 1, 9.4\% of the CEOs in the sample are women. By contrast, Huang and Kisgen (2013) document that only 2\% of the CEOs of large publicly traded U.S. companies are women. The higher number (as well as percentage) of female executives in our sample is, at least in part, due to the inclusion of a large number of private firms in our sample. Consistent with this, our data show that the percentage of female CEOs is higher among privately-held firms (10.2\%) than among publicly-traded firms (7.2\%).

\subsection{Risk-Taking}

We consider three measures of risk-taking. The first measure, Leverage, is a measure of the riskiness of corporate financing choices. The intuition is simple: given a (negative) shock to a firm's underlying business conditions, the higher the leverage, the greater the (negative) impact of the shock on the firm's net profitability (including a higher probability of default). Leverage is defined as the ratio of financial debt divided by the sum of financial debt plus equity. Financial debt is the sum of long term debt (excluding "other non-current liabilities") and short term loans. Across the firms in our sample, the average Leverage ratio is $37.4 \%$. This ratio is $32.4 \%$ for firms with a female CEO and 37.9\% for firms with a male CEO (the p-value of the difference between the two is less than 0.001).

The other two risk-taking variables are measures of the riskiness of outcomes. $\sigma(R O A)$ is the volatility of the firm's operating return on assets, defined as the ratio of earnings before 
interest and taxes to total assets. Volatility of returns is a standard proxy for risk in the financial economics literature. This variable captures the riskiness of investment decisions. Further, earlier work by John et al. (2008) establishes that the volatility of firm-level operating profits has a positive impact on long term economic growth. We focus on the volatility of accounting returns (as opposed to stock market returns) as the vast majority of firms in our sample are privately held. We calculate the standard deviation of the returns over 5-year overlapping windows (19992003, 2000-2004, 2001-2005, 2002-2006, 2003-2007, 2004-2008 and 2005-2009). Across all firms in the sample, the average volatility of ROA is $4.8 \%$. As with Leverage, there is a significant difference in this variable (p-value $<0.001$ ) between firms run by female CEOs (2.7\%) and firms run by male CEOs (5.0\%).

Third, we exploit the notion that riskier firms are less likely to survive, and focus on the likelihood of surviving over a 5-year period. For a firm to enter this analysis, we only require that CEO gender, ownership, and accounting data be available for at least one year during 19992005. Since firms that enter our sample in 2005 or earlier could have up to five years or more of data, we focus on these observations to assess the likelihood of survival. This specification has two main advantages. First, there is no survivorship bias, as both surviving and non-surviving companies are included in the analysis. Second, this measure of risk-taking is unaffected by accounting manipulation. We find that $51.7 \%$ of the firms in the sample survive at least 5 years. The likelihood of survival is $61.4 \%$ for firms with a female CEO and $50.5 \%$ for firms with a male CEO. The difference between female and male CEOs is statistically significant with a pvalue of less than 0.001 . 


\subsection{Control Variables}

The models employed in our analyses include a number of firm-level control variables. $R O A$ is defined as the ratio of earnings before interest and taxes to total assets. We include firm profitability to control for differences in management quality. Sales Growth is calculated as the annual rate of growth of sales. Since most of the firms in the sample are private, we use sales growth (rather than the market-to-book ratio) as a control variable. $\operatorname{Ln}$ (Size) is the natural log of total assets (in thousands US\$), expressed in 2000 prices. ("Total assets" is the sum of fixed assets (tangible and intangible fixed assets and other fixed assets) and current assets (inventory, receivables, and other current assets).) $\operatorname{Ln}(1+$ Age $)$ is the natural logarithm of $(1+$ the number of years since incorporation). This variable controls for differences in the life cycle/stage of a firm. Tangibility is calculated as the ratio of fixed to total assets. Private firm is an indicator denoting firms that are not publicly traded. We use this variable as a proxy for capital constraints. Cash flow rights is the ownership rights of the largest ultimate shareholder. ${ }^{10}$ The higher the ownership of a large shareholder, the greater the incentive to monitor the CEO. This would in turn mitigate agency conflicts. CEO Ownership is calculated as the cash flow rights of the CEO on the firm's earnings. Since a high level of ownership aligns the CEO's incentives with those of minority shareholders, we use CEO ownership to control for agency conflicts.

In some of the models we also control for CEO age and CEO wealth. However, the availability of data on these additional CEO characteristics is limited. Adding these controls thus considerably reduces the sample size. For this reason, these controls are not included in all the tests. The inclusion of these controls is motivated by earlier evidence suggesting that younger

\footnotetext{
${ }^{10}$ To identify the largest ultimate shareholder, for each company that has available ownership data in Amadeus, we identify its owners, the owners of its owners, and so on.
} 
CEOs (Taylor, 1975, Kovalchik, Camerer, Grether, Plott, and Allman, 2005, Forbes, 2005) and wealthier CEOs (Arrow, 1984, Paravisini, Rappoport, and Ravina, 2015, Calvet and Sodini, 2014) are more prone to take risks. Data in Amadeus allow us to construct a proxy for the equity wealth for a subsample of CEOs. To determine the equity wealth for each CEO, we first calculate the dollar value of the investment in each firm in which he/she appears as a shareholder. This is computed by multiplying the individual's ownership in the firm by the firm's book value of equity. (We use book values because most of the firms in the sample are privately-held). Next, we sum the value of all equity investments to obtain each CEO's total equity wealth.

To reduce the impact of outliers, we winsorize the accounting variables (other than sales growth, $\sigma(R O A)$, and leverage) at the top and bottom $1 \%$ of the distribution. Since sales growth, $\sigma(R O A)$, and leverage exhibit large positive skewness, these three variables are winsorized at the bottom $1 \%$ and at the top $5 \%$ of the distribution.

Summary information for all the variables is reported in Table 1. The sample includes 132,590 firms and 338,397 firm-year observations. A comparison of the sample means for firms run by female and male CEOs reveals important differences in the characteristics of both firms and CEOs. Firms run by female CEOs tend to be older and more profitable. In contrast, firms run by male CEOs tend to be larger and grow at faster rates. The fraction of private firms is higher among those run by a female CEO. With respect to CEO characteristics, we notice that female CEOs tend to own a larger share of the equity of the firms that they run. At the same time, these firms have a more dispersed ownership structure. Male CEOs tend to be, on average, marginally wealthier and older than female CEOs. 


\section{CEO Gender and Corporate Risk-Taking}

To investigate the relation between CEO gender and corporate risk-taking, we start by regressing our measures of risk-taking on CEO gender and other determinants of risk-taking that, if excluded, could induce spurious correlations. The results are reported in Table 2. Leverage is the dependent variable in Regression (1). Regression (1) is a panel ordinary least squares (OLS) regression with standard errors clustered at the firm level. The results of Regression (1) indicate that firms run by female CEOs use significantly less leverage and therefore take less financial risk than firms run by male CEOs. The coefficient of Female CEO indicates that after controlling for several other determinants of capital structure choices, the leverage of firms run by female CEOs is 0.034 lower on average than the leverage of firms run by male CEOs. This appears to be a sizeable difference, given an average value of Leverage of 0.374 for the entire sample. The coefficient on the gender variable has a p-value of less than 0.001 .

The volatility of firm-level profitability $(\sigma(R O A))$ is the dependent variable in Regression (2). We again employ a panel OLS specification with standard errors clustered at the firm level. In this Model (as well as in Regression (3)), all independent variables are measured at the first year-end of the five-year sample period over which the volatility of earnings (or the likelihood of survival) is measured. The results show that the volatility of a firm's ROA is significantly lower when the firm is run by a female CEO (p-values $\leq 0.001$ ). As with Leverage, the difference in the volatility of firm-level profitability between firms run by female and male CEOs is sizeable $(1.998 / 100=0.020)$ relative to the sample mean $(0.048)$.

Regression (3) is a cross-sectional probit regression of the Likelihood of survival, in which the outcome is 1 if a company survives for at least five years and 0 otherwise. The results 
in Table 2 indicate significantly higher survival rates for companies run by female CEOs. To the extent that firms that take more risk are less likely to survive through time, this result is consistent with the notion that companies managed by women tend to engage in less risky projects.

Thus, in the cross-section, both corporate choices (such as leverage) and corporate outcomes (volatility of profitability and the likelihood of survival) vary significantly depending on the gender of the CEO.

However, the comparison of the firm and CEO characteristics tabulated in Table 1 makes the issue of non-random selection immediately apparent. To mitigate sample selection concerns in the comparison of firms run by female and male CEOs, in the remainder of this Section we analyze four different samples: (1) a propensity score matched sample; (2) a sample of firms experiencing a transition from male to female CEOs or vice-versa; (3) a propensity score matched sample of firms undergoing a CEO transition; and (4) a treatment effects model.

\subsection{Propensity Score Matched Samples}

We begin our analysis of the differences in corporate risk-taking between female and male CEOs by employing a propensity score matching procedure (Rosenbaum and Rubin, 1983). This methodology allows us to identify a control sample of firms that are run by male CEOs and that exhibit no observable differences in characteristics relative to the firms run by female CEOs. Thus, each pair of matched firms is virtually indistinguishable from one another except for one key characteristic: the gender of the CEO. Matching on observable firm- and CEOcharacteristics mitigates (but does not eliminate) concerns related to non-random selection.

To implement this methodology, we first calculate the probability (i.e., the propensity score) that a firm with given characteristics is run by a female CEO. We start by calculating this 
probability as a function of firm-level characteristics. More specifically, in Panel A of Table 3, the propensity score is estimated within a country-industry-year-public/private status category, as a function of ROA, sales growth, the natural log of total assets, the natural log of firm age, asset tangibility, the ownership of the CEO, and the ownership of the largest ultimate shareholder. To ensure that the firms in the control sample are sufficiently similar to the firms run by a female CEO, we require that the maximum difference between the propensity score of the firm run by a female CEO and that of its matching (male CEO run) peer does not exceed $0.1 \%$ in absolute value.

[Insert Table 3 here]

A comparison of Leverage, $\sigma(R O A)$, and Likelihood of survival between the matched samples reveals that, firms with female CEOs tend to take less risk than firms with male CEOs even when several other observable characteristics between the firm pairs are virtually identical. As the results in Panel A of Table 3 show, the average leverage of firms run by female CEOs is 33.1\%, compared with $36.2 \%$ for otherwise similar firms run by male CEOs. The average volatility of ROA is $2.6 \%$ for firms run by female CEOs and $4.1 \%$ for firms run by male CEOs. The likelihood of survival over a five-year period is $66.2 \%$ for firms run by female CEOs and $56.3 \%$ for firms run by male CEOs. All differences in risk-taking between the two groups are statistically significant with p-values of less than 0.001. Importantly, these results suggest that the gender-related differences in risk-taking observed in the univariate analysis are not due to observable differences in firm characteristics.

In Panel B of Table 3 we match firms within a country-industry-year-public/private status category, as a function of firm-level and CEO-level characteristics (namely, CEO wealth and 
CEO age) that are available on a more limited basis. Even with this very restrictive matching, our conclusions remain unchanged.

\subsection{Regression Analysis of Transition Firms}

A limitation of the propensity score matching results is that the documented correlation between CEO gender and corporate risk-taking may simply reflect unobservable characteristics that influence both CEO gender choice and corporate risk-taking choices. The omission of these controls might lead us to incorrectly attribute the differences in risk-taking to differences in CEO gender.

In this section, we exploit the panel dimension of our dataset to control for time-invariant firm-specific characteristics that may be correlated with omitted explanatory variables. For this purpose, we run (panel) regressions with firm fixed effects. The inclusion of firm fixed effects in the regression models removes any purely cross-sectional correlation between gender and risktaking, reducing the risk of spurious correlation. In particular, in firm fixed effects regressions, we compare CEOs of different genders operating the same firm.

In this analysis, we include only firms that experience a change from a male CEO to a female CEO or vice versa, as only those firms contribute to the identification. Leverage is the dependent variable in Regression (1) of Table 4. Regression (1) is a panel regression with firm fixed effects and standard errors clustered at the firm level. The results indicate that firms run by female CEOs use significantly less leverage and therefore take less financial risk than firms run by male CEOs. The coefficient of Female CEO indicates that after controlling for several other determinants of capital structure choices, a firm's leverage is 0.028 lower, on average, when the firm is run by a female CEO vs. when the same firm is run by a male CEO. This appears to be a 
sizeable difference, given an average value of Leverage of 0.374 for the full sample. The coefficient on the gender variable has a p-value of less than 0.001 .

[Insert Table 4 here]

The volatility of firm-level profitability $(\sigma(R O A))$ is the dependent variable in Regression (2). We again employ a panel specification with firm fixed effects and standard errors clustered at the firm level. In this Model (as well as in Regression (4)), all independent variables are measured at the first year-end of the five-year sample period over which the volatility of earnings is measured. The results show that the volatility of a firm's ROA is significantly lower when the firm is run by a female CEO ( $\mathrm{p}$-values $\leq 0.001$ ). As with Leverage, the difference in the volatility of firm-level profitability between firms run by female and male CEOs is sizeable $(1.584 / 100=0.016)$ relative to the sample mean $(0.048)$.

A possible concern with the analysis of CEO transitions is that they are likely to be accompanied by changes in CEO characteristics other than gender. To the extent that these characteristics affect risk-taking and have been omitted from the previous analyses, we could have incorrectly attributed the change in risk-taking observed at the time of a transition to gender. We note that for non-gender-related CEO (or any) characteristics to explain the gender results, changes in these characteristics must (1) occur around the time of the transition (as in the firm fixed-effects specifications identification comes from time series changes); (2) be different for the subsample of firms (initially) run by male CEOs and female CEOs; and (3) credibly affect risk-taking choices.

To address this concern, we add controls for two CEO-level characteristics (CEO age and CEO wealth) that we are able to observe at least for some of the firms in our sample. 
Importantly, the regression results in the last two columns of Table 4 continue to show differences in risk-taking across genders after controlling for these additional CEO characteristics. This mitigates the possibility that our results might be due to time-varying, CEOspecific omitted variables. Admittedly, we recognize that we cannot control for other potentially relevant CEO characteristics that might change around the time of transitions. Therefore, with this test we cannot rule out the omitted variable issue completely.

\subsection{Propensity Score Matching Analysis of Transition Firms}

One specific concern with the transition sample is that transitions occur at "special" times. The inclusion of firm fixed effects in the regression models is not sufficient to address this selection concern. To better address this concern, in Table 5 we present a propensity score analysis of the firms experiencing a transition from male to female CEOs. ${ }^{11}$ To minimize the possible impact of confounding events, those firms are matched with a control group of firms that are run by male CEOs during the entire sample period. In this analysis, we match firms within a country-industry-year-public/private status category as a function of firm-level characteristics.

[Insert Table 5 here]

We find that transition firms on average experience a reduction in Leverage from an average of 0.400 (under a male CEO) to an average of 0.374 (under a female CEO). This change is statistically significant with a p-value of less than 0.001 . By contrast, the leverage of otherwise similar firms that were always run by a male CEO does not change significantly during the same

\footnotetext{
${ }^{11}$ For the subset of firms experiencing a transition from female to male CEOs, we find a significant increase in risk-taking after the transition. However, we do not have enough control firms (i.e., firms always run by female CEOs) from the same country-industry-year and public/private status category to undertake a propensity score analysis using the matching algorithm described above.
} 
time periods. The difference between the change in leverage of the transition firms and that of the control group is statistically significant with a p-value of less than 0.001 . Similar conclusions obtain when we look at the change in the volatility of firm level profitability, $\sigma(R O A)$. While we again acknowledge that CEO gender might not be randomly assigned, this result provides additional evidence of changes in corporate risk-taking around CEO transitions.

\section{III.D. Endogenous Matching Between Firms and CEOs}

Our results thus far document an economically and statistically significant association between CEO gender and corporate risk-taking. The propensity score approach and the analysis of CEO transitions help mitigate omitted variables concerns. However, as we have discussed, those methodologies are not free of possible limitations. Importantly, the differences in risktaking observed between firms run by male and female CEOs are not purely cross-sectional, as our time-series analysis of CEO transitions shows that transitions are associated with changes in corporate risk-taking. Therefore, any proposed mechanism behind the observed association between CEO gender and corporate risk-taking needs to be able to explain why risk-taking changes around CEO transitions.

To investigate the extent to which self-selection might explain our results, we employ a variation of the Heckman (1979) two-step approach: the treatment effects model. The first stage of this model is a binary outcome equation (specifically, a probit equation) which models the choice of hiring a male or female CEO. In the second step, we include the inverse Mills ratio (derived from the first stage) alongside an indicator variable characterizing CEO gender and our prior controls. 
To facilitate identification, in the first stage we use an exogenous determinant of the likelihood that the board might appoint a female CEO. In prior work, Grinblatt and Keloharju (2001), Huberman (2001), and Seasholes and Zhu (2010), among others, document that familiarity appears to be important to investors in an investment setting. ${ }^{12}$ We borrow from these studies and build on the notion of familiarity to develop an instrument.

To proxy for familiarity, we suggest that male board members who serve on other boards with female CEOs are more familiar with working with women in executive roles. To the extent that their participation in these boards reflects an appreciation and familiarity with female executives, they might be more inclined to propose a woman for the position of CEO. With this in mind, we focus on the fraction of firms with a female CEO among all other firms in which the firm's male directors also serve as directors. More specifically, among all other firms in which the firm's male directors also serve as directors, we compute the fraction of firms with (1) a female CEO, (2) above-average leverage, (3) above-average volatility of ROA in the subsequent five years, and (4) lack of survival during the following five years. A benefit of using this fractional measure is that it does not vary based on the number of boards on which a director sits. This mitigates any concern that the variable might correlate with connections through networks, which would likely not satisfy the exclusion restriction.

We recognize that this strategy is not without caveats. However, for an omitted variable to explain our results, this variable would need to explain (1) CEO gender selection, (2) board selection, (3) below-average risk-taking for the firm in question and (curiously), at the same time, (4) above-average risk-taking among the other firms in which the firm's male directors serve (we focus on this scenario, by choice, in the construction of our instrument). Any omitted

\footnotetext{
${ }^{12}$ Somewhat consistent with this idea, Farrell and Hersch (2005) document that the probability that a woman is added to the board significantly increases following the departure of a female director.
} 
variable responsible for our main results would need to explain all of these (often opposing) outcomes, which certainly stands in contrast to a basic "law of simplicity."

Another potential concern is that the sample of firms in which the firm's male directors also serve as directors which have (1) a female CEO and (2) above-average risk-taking is relatively small - - 3,674 observations in Regression (1) of Table 6. We leave it to the readers to decide whether such a sample is too small to draw any inferences. At minimum, however, we notice that the different methodologies employed so far to address causality appear to provide consistent evidence.

In line with our prediction, we find that our proxy for familiarity is correlated with CEO gender (see Panel A of Table 6). Further, the inverse Mills ratio is marginally significant in two out of three regressions in Panel B of Table 6. Importantly, in each and every second stage model, CEO gender remains statistically significant after controlling for self-selection due to unobserved firm or CEO characteristics; if anything, the magnitude of the CEO gender coefficient estimates becomes greater after controlling for self-selection. ${ }^{13}$

[Insert Table 6 here]

Despite all the tests employed to address the issue of endogeneity (firm fixed effects, CEO transitions, propensity score matching, and treatment effects models), we find little evidence that the endogenous matching between firms and CEOs explains the documented association between CEO gender and corporate risk-taking. While causality represents a possible explanation for the changes in risk-taking observed following CEO transitions, explicitly testing for causality remains a challenge (given the impossibility of randomly assigning CEOs to firms).

\footnotetext{
${ }^{13}$ We also employed a second variation of the Heckman's (1979) two-step procedure: a switching regression analysis with endogenous switching. Untabulated results show that for firms run by female CEOs, risk-taking choices (leverage) and outcome (volatility of ROA and survival) would have been higher had the firms been run by a male CEO. Results are available upon request.
} 
With these caveats in mind, however, these tests confirm the previous evidence and suggest that, even after controlling for self-selection, women CEOs tend to take on less risk compared to their male counterparts.

\section{CEO Gender and the Efficiency of Capital Allocation}

So far we have documented that female CEOs make less risky corporate choices than male CEOs. To the extent that this outcome is driven by female CEOs imposing their preferences on corporate choices, the efficiency of the capital allocation process may be undermined. In this section, we investigate whether this appears to be the case. We employ two approaches to measure the efficiency of capital allocation. First, we use the approach proposed by Wurgler (2000) - - and use value added growth to proxy for the quality of investment opportunities. Second, we look at the degree to which investment is related to the marginal (Tobin's) Q, as advocated by theory. The Wurgler approach is discussed in Section 4.1. The marginal Tobin's Q approach is discussed in Section 4.2. In Section 4.3., we discuss the possible explanations for the lesser degree of efficiency of capital allocation observed among female CEOs.

\subsection{Value Added Growth}

In order to achieve an efficient allocation, capital should be invested in sectors with good investment opportunities and be withdrawn from those sectors that have poor investment opportunities. Wurgler (2000) proposes that optimal investment implies investing more in growing industries and decreasing investment in declining industries. He points out that, since Gross Domestic Product (GDP) is the sum of the value added across all the firms in the economy, and given that economic growth is often measured as growth in GDP, looking at 
growth in value added is a natural way to measure growth. Accordingly, value added growth is used as a proxy for the quality of investment opportunities.

In this section, we follow this insight and estimate the sensitivity of investment to the growth in value added. Value added growth is computed as the difference between the natural $\log$ of value added in year $t$ and the natural $\log$ of value added in year $t-1$. Value added, in constant US dollars (year 2000 prices), is defined as earnings before interest and taxes plus the cost of employees. The richness of our data allows us to measure value added growth at the firm level.

To assess the efficiency of capital allocation, for all companies in Amadeus, we estimate a simple version of the Fazzari et al. (1988) model of investment, augmented by an indicator denoting a female CEO and the interaction of this indicator with each firm's growth in value added: ${ }^{14}$

$$
\begin{gathered}
\frac{\Delta \text { Gross PPE }_{j, t}}{\text { Total Fixed Assets }_{j, t-1}}=\alpha+\beta \cdot \ln \frac{\text { Value Added }_{j, t}}{\text { Value Added }_{j, t-1}}+ \\
+\gamma \cdot \frac{\text { Cash Flow }_{\mathrm{j}, \mathrm{t}}}{\text { Total Fixed Assets }_{j, t-1}}+\delta \cdot \operatorname{Ln}\left(1+\text { Age }_{j, t}+\zeta \cdot \text { Female CEO }_{j, t}+\right. \\
+\theta \cdot \ln \frac{\text { Value Added }_{j, t}}{\text { Value Added }_{j, t-1}} \cdot{\text { Female } C E O_{j, t}}+\mathrm{u}_{\mathrm{j}, \mathrm{t}}^{\mathrm{i}}
\end{gathered}
$$

where $\frac{\Delta \operatorname{Gross} \operatorname{PPE}_{j, t}}{\text { Total Fixed Assets } j, t-1}$ represents the capital expenditures of firm $j$ at time $t$, relative to the capital stock; $\triangle$ Gross $P P E_{j, t}$ is the annual change in net Total Fixed Assets, with depreciation added back; Total Fixed Assets is the sum of tangible fixed assets, intangible fixed assets, and

\footnotetext{
${ }^{14}$ See Hubbard (1998) and Bond and van Reenen (2007) for extensive surveys on alternative models on investment. As in Wurgler (2000), we rely on a relatively simple regression specification as more elaborate specifications give similar results.
} 


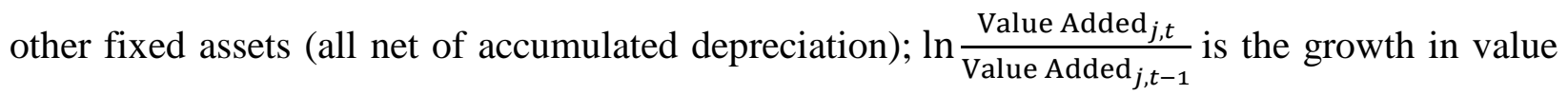
added and it reflects the quality of the firm's investment opportunities; Cash Flow f $_{, t}$ is net income plus depreciation. $\operatorname{Ln}(1+A g e)_{j, t}$ is the natural logarithm of $(1+$ the number of years since incorporation). We control for firm age to capture the possibility that risk-taking may be dependent on the stage of the firm. $\beta$ represents the sensitivity of investments to growth opportunities. Ceteris paribus, the better (worse) the growth opportunities, the more a value maximizing-value manager should invest (divest). $\theta$ is our coefficient of interest which measures the difference in the investment sensitivity to growth opportunities between firms run by female and male CEOs. If CEO gender is “irrelevant” for investment efficiency, then $\theta=0$.

Table 7, Panel A, presents regressions of firm investment on value added growth, CEO gender, the interaction between these two variables, and other controls. In the estimation, we add firm and year fixed effects to mitigate endogeneity concerns from omitted variables. Consistent with optimal capital budgeting, the results in Table 7 show that there is a positive and significant association between investments and value added growth for firms run by male CEOs. For example, Regression (1) shows that, for male CEOs, the coefficient of the sensitivity of investment to growth opportunities is 0.154 , with a p-value of less than 0.001 . In other words, these results are consistent with male CEOs investing more when their firm is operating in an industry with good prospects, and divesting capital (or invest less) when the prospects of their firm are poor.

By contrast, the coefficient on the interaction between CEO gender and value added growth is negative and significant (coeff. $=-0.073$, p-value $<0.001$ ), implying that, corporate investments are less responsive to value added growth in firms run by female CEOs. This result 
suggests that women do not appear to allocate capital as efficiently as male CEOs. In unreported tests we find that the results are robust to including other controls such as ownership concentration, profitability, sales growth, firm size, asset tangibility, and a private firm indicator. Regression (2) indicates the results are also robust to using a treatment effects specification which partially controls for the endogeneity of the CEO selection choice.

To assess the extent to which risk-avoidance is associated with less efficient capital allocation in firms run by female CEOs, in Regression (3) we augment our specification with both an index that measures the degree of risk-avoidance and the interaction of this index with value added growth. We construct an index based on the three variables used to measure the degree of risk-avoidance. In particular, the index is constructed by adding 1 when (1) a firm's leverage is in the bottom $20 \%$ of the distribution; (2) the volatility of firm-level profitability is in the bottom $20 \%$ of the distribution; and (3) if the firm survives at least 5 years. The index ranges from 0 to 3, with higher scores denoting greater risk-avoidance. As shown in Regression (3), the risk-avoidance index is negatively correlated with the level of investment, indicating that more risk-averse CEOs invest less.

\subsection{Marginal $Q$}

To assess the efficiency of capital allocation, we also evaluate the extent to which investment is related to the marginal $\mathrm{Q}$, as advocated by theory. While marginal $\mathrm{Q}$ is a theoretically grounded measure of the quality of investment opportunities, using Q becomes problematic if firm valuation is contaminated by investor sentiment or if there is mispricing of any kind. Additionally, marginal Q can only be computed for publicly traded firms. The extent to which it can be used to proxy for the quality of investment opportunities faced by (predominantly) private firms is, of course, subject to debate. With those caveats in mind, we 
note that optimal decision making in perfect capital markets requires that managers undertake all projects with positive expected net present value, and reject all projects with negative expected net present value. If projects were to be ranked based on their expected net present value per dollar of capital invested, managers should invest up to the point where, for the next project in line, the net present value is zero. By doing so, managers would maximize firm value. Equivalently, managers should invest up to the point where the firm's marginal Q is 1. A firm's marginal $\mathrm{Q}(\dot{q})$ measures the change in the market value of firm, $\Delta \mathrm{V}$, associated with an (unexpected) change in capital investment, $\Delta \mathrm{I}$. In other words,

$$
\dot{q}=\frac{\Delta \mathrm{V}}{\Delta \mathrm{I}}=\frac{1}{\mathrm{C}}\{\mathrm{E}[\mathrm{NPV}]+\mathrm{C}\}
$$

where $C$ represents the set-up cost for the capital investment, and E[NPV] is its expected net present value or, equivalently, the present value of all incremental cash flows yielded by the project in the future (net of its set-up cost). For any given C $>0$, E[NPV] $>0$ implies a $\dot{q}>1$. Conversely, E[NPV] $<0$ implies a $\dot{q}<1$. Stated differently, value maximization implies $\dot{q}=1$. A $\dot{q}>1$ implies underinvestment, while a $\dot{q}<1$ implies overinvestment.

To estimate $\dot{q}$, we largely follow Durnev et al. (2004). A few changes to their methodology are necessary because of differences in corporate disclosure in Europe. For clarity, in Appendix A we describe each step employed in the estimation procedure, largely borrowing from Durnev et al. (2004) paper. As shown earlier in Table 1, the average marginal Q is 1.123, and the median is 0.948 . We find a great deal of variation in the estimates of the marginal Q across industries. Interestingly, the marginal Q does not cluster around 1, as we would expect if, across all industries, firms were investing up to the "optimal point.” Rather, there is evidence of both underinvestment and overinvestment in different industries. 
As with value added growth, to assess the efficiency of capital allocation, we estimate a simple version of the Fazzari et al. (1988) $q$-model of investment, as in equation (1). In the new model, we replace firm-level value added growth with marginal Q. Table 7, Panel B, presents regressions of firm investment on marginal Q, CEO gender, the interaction between these two variables, and other controls. (In this Panel, we use bootstrapped standard errors as marginal Qs are estimated.) We include country, industry and year fixed effects to mitigate measurement error problems in the estimation of marginal Q. As we pointed out above, under perfect capital markets, optimal capital budgeting requires that managers undertake all (and only) positive expected net present value projects. Equivalently, managers should undertake all investments with $\dot{q}>1$, and avoid (or divest) those with $\dot{q}<1$. As a consequence, given the presence of differences in the quality of investment opportunities across industries, optimal capital budgeting implies a positive relation between investments and each industry’s marginal Q, $\dot{\hat{\mathrm{q}}}_{\mathrm{t}}^{\mathrm{i}, \mathrm{c}}$.

Consistent with optimal capital budgeting, and in line with the results in Panel A of Table 7, the results in Panel $\mathrm{B}$ show that there is a positive and significant association between investments and Tobin's Q for firms run by male CEOs. For example, Regression (1) shows that, for male CEOs, the coefficient of the sensitivity of investment to marginal Q is 0.013 , with a pvalue of less than 0.001. By contrast, the coefficient on the interaction between CEO gender and marginal $\mathrm{Q}$ is negative and significant (coeff. $=-0.020$, p-value $<0.001$ ), once again implying that corporate investments are less responsive to marginal Q in firms run by female CEOs. This result, again, suggests that women do not appear to allocate capital as efficiently as male CEOs. As with Panel A, Regression (2) indicates that the results are robust to using a treatment effects specification to control for the endogeneity of the CEO selection choice. 
In Regression (3) we augment our specification with the index that measures the degree of risk-avoidance and the interaction of this index with marginal Q. As the Table shows, the riskavoidance index is negatively correlated with the level of investment, corroborating the earlier results that more risk-averse CEOs invest less. In addition, the index's interaction with marginal Q indicates that investment is less sensitive to marginal Q when risk-avoidance is high.

\subsection{Interpretation of the Evidence}

There are two possible (non-mutually exclusive) explanations for the less efficient capital allocation observed among female CEOs. The first is underinvestment. This would occur if female CEOs do not undertake some of the projects with positive net present value (NPV). Underinvestment implies that women "leave money on the table" by not undertaking all available positive NPV investment opportunities. For example, to the extent that the impact of gender or risk-taking depends on the stage of the firm, for firms with high growth opportunities, female CEOs may be too risk-averse to increase investment. The second source of inefficiency is overinvestment. This occurs if women do not avoid (and/or do not divest) projects with negative NPV. For example, for firms with poor investment opportunities, female CEOs may be reluctant to make divestitures and thus overinvest. Unfortunately, due to data limitations, the precise channel behind our results is difficult to identify empirically. More specifically, Amadeus Top 250,000 does not report gross investment and divestitures separately. Instead, we are only able to observe net investments.

\section{Discussion}

Besides traditional explanations such as agency and informational asymmetries, possible economic reasons for why CEO gender could "influence” risk-taking include (but are not limited 
to) more pronounced risk-aversion in female CEOs (compared to male peers), less overconfidence, differences in incentives structures, differences in unemployment risk, and social norms. In this Section we discuss alternatives to these traditional explanations.

To the extent that female executives tend to be more risk-averse on average than their male peers, women might choose to reduce corporate risk-taking to a level that fits their preferences once they have become CEOs. Indeed, the experimental economics and psychology literature have documented gender-related differences in preferences and risk tolerance (see Croson and Gneezy (2009) and Bertrand (2011) for surveys). ${ }^{15}$ However, we recognize that while it is well documented women are less risk tolerant than men in general (Hudgens and Fatkin (1985), Bruce and Johnson (1994), Johnson and Powell (1994), Sundén and Surette (1998) and Bernasek and Shwiff (2001)), there may not necessarily be a difference between males and females among top executives, given the specific and rare combination of skills needed to ascend to a high management position (Adams and Funk, 2012, Adams and Ragunathan, 2013). ${ }^{16}$

The results are also consistent with the possibility that less overconfident agents reduce risk after they become CEOs. In the behavioral literature, women are typically found to be less overconfident than men, at least (on average) in the population (e.g., Lundeberg et al. (1994); Barber and Odean (2001)). Huang and Kisgen (2013) conclude that male executives appear to be more overconfident than female executives documenting that female executives are less likely to engage in acquisitions and less likely to issue debt than male executives.

\footnotetext{
${ }^{15}$ These differences could have biological roots (e.g., Bröder and Hohmann, 2003; Maestripieri et al. (2009) could be the outcome of environmental influences (e.g., Booth and Nolen, 2012), or both (e.g., Edwards and O’Neal, 2009).

${ }^{16}$ The empirical evidence on this point is mixed. While Bandiera et al. (2015) provide survey-based evidence that Italian female managers are on average less risk tolerant than their male peers, Adams and Funk (2012) find Swedish female directors to be on average less risk-averse than male directors.
} 
Differences in the structure of compensation and incentives may also explain the documented association between gender and risk-taking. In particular, low risk firms may be more likely to offer fixed pay contracts and may be more likely to attract female executives. Consistent with this type of matching, in Bandiera et al.'s (2015) model more risk-averse and less talented managers match with firms offering low-powered incentives -- a prediction that they confirm empirically using survey data on Italian managers combined with longitudinal data from administrative records. Using survey data from the British Workplace Employees Relations Survey, Manning and Saidi (2010) report fewer women in establishments that use variable (as opposed to fixed) pay. ${ }^{17}$

Additionally, unemployment risk differences faced by different sets of agents may also influence their matching choice or help explaining any causal impact of gender on corporate choices. More specifically, if corporate risk-taking is positively correlated with the likelihood that a CEO loses his/her job, and if finding a new job is more difficult for women than men, women might choose to self-select into low risk firms or to reduce firm risk once they have become a CEO. Indeed, across the countries and over the time period included in our study, the average unemployment rate among women who previously held a managerial position is $3.9 \%$. By comparison, this rate is $2.7 \%$ for men. ${ }^{18}$ Earlier studies further document that women tend to remain unemployed for longer periods than men after losing a managerial job (Phelps and Mason, 1991).

Finally, expectations by society about what is appropriate for women to do (see, for example, Altonji and Blank (1999), Akerlof and Kranton (2000), and Guiso et al. (2008)) may

\footnotetext{
${ }^{17}$ It is however unclear whether there is any systematic gender pay gap at the CEO level. For example, using recent U.S. data on CEO pay, Bugeja et al. (2012) find no evidence of a gender pay gap at the CEO level. Geiler and Renneboog (2015) reach a similar conclusion using a U.K. sample - - although these authors document gender pay gaps for lower ranked executives.

${ }^{18}$ These statistics are computed using data from the European Labour Force Survey.
} 
affect not only a woman's decision to work, but also the sorting of men and women across occupations, industries and firms. These societal expectations might also affect the choices that women make in specific occupations (such as CEO). In a seminal study by Akerlof and Kranton (2000), deviating from the behavior that is expected by society decreases the agent's utility. To the extent that a society expects women to stay at home, the model predicts a lower participation of women to the workforce. Their model also explains occupational segregation by gender, which is further validated by Goldin (1990), Altonji and Blank (1999), and Bertrand et al. (2010). To the extent that managing high risk firms involves longer working hours and less flexible schedules, women might disproportionately self-select into low risk firms to be better able to accommodate the child rearing and household tasks that they often disproportionately carry (Goldin and Katz (2010)). Women might also reduce corporate risk-taking to a level that is compatible with their personal constraints after they become CEOs.

Of course, the documented association between CEO gender and corporate risk-taking could be the outcome of endogenous matching between firms and CEOs. While in our analyses we attempted to mitigate this possibility, we recognize that non-random matching cannot be ruled out.

\section{Conclusions.}

We investigate how CEO gender relates to corporate risk-taking choices. We document that firms run by female CEOs tend to make financing and investment choices that are less risky than those of otherwise similar firms run by male CEOs. Further, an analysis of changes in risktaking around CEO transitions indicates that the risk-taking of a given firm tends to decrease (increase) around the transition from a male to a female CEO (or vice-versa). The documented 
change in risk-taking around CEO transitions is over and beyond what is observed around a matched sample of peers that are always run by male CEOs.

Overall, at least in our sample, it appears that women who climbed the corporate ladder are different from their male peers. The results do not appear to be driven by unobserved CEO or firm traits that could give rise to non-random self-selection. Specifically, a multitude of tests indicate that, even after controlling for self-selection, women CEOs tend to take on less risk compared to their male counterparts. Importantly, in our large sample of female CEOs, we document that gender-related differences in risk-taking documented in experimental economics and psychology studies extend to top corporate executives.

We further show that the risk-avoidance of female CEOs appears to have implications for the efficiency of the capital allocation process. We observe a positive association between the quality of investment opportunities and the level of investments for firms run by male CEOs, while this association is significantly weaker among firms run by female CEOs. Thus, female CEOs do not appear to allocate capital as efficiently as male CEOs. 


\section{Appendix A. Estimation of a firm's marginal Q $(\dot{q})$}

To estimate $\dot{q}$, we rewrite (2) as

$$
\dot{\mathrm{q}}_{\mathrm{j}, \mathrm{t}}=\frac{\mathrm{V}_{\mathrm{j}, \mathrm{t}}-\mathrm{V}_{\mathrm{j}, \mathrm{t}-1}\left(1+\hat{\mathrm{r}}_{\mathrm{j}, \mathrm{t}}-\widehat{\mathrm{d}}_{\mathrm{j}, \mathrm{t}}\right)}{\mathrm{A}_{\mathrm{j}, \mathrm{t}}-\mathrm{A}_{\mathrm{j}, \mathrm{t}-1}\left(1+\hat{\mathrm{g}}_{\mathrm{j}, \mathrm{t}}-\widehat{\delta}_{\mathrm{j}, \mathrm{t}}\right)}
$$

where $\dot{\mathrm{q}}_{\mathrm{j}, \mathrm{t}}$ is the marginal Q of firm $j$ at time $t . \mathrm{V}_{\mathrm{j}, \mathrm{t}}$ is the market value of firm $j$ at time $t$, and $\mathrm{A}_{\mathrm{j}, \mathrm{t}}$ is the stock of capital of firm $j$ at time $t$. $\widehat{\mathrm{r}}_{\mathrm{j}, \mathrm{t}}$ is the expected return from owning $j$; $\widehat{\mathrm{d}}_{\mathrm{j}, \mathrm{t}}$ is the expected disbursement rate to providers of capital; $\hat{\mathrm{g}}_{\mathrm{j}, \mathrm{t}}$ is the expected rate of growth of the stock of capital; and $\widehat{\delta}_{j, t}$ is its expected rate of depreciation. Thus, $V_{j, t}-V_{j, t-1}\left(1+\widehat{r}_{j, t}-\widehat{d}_{j, t}\right)$ is the change in the market value of firm and $A_{j, t}-A_{j, t-1}\left(1+\hat{g}_{j, t}-\widehat{\delta}_{j, t}\right)$ is the unexpected change in the stock of capital.

Equation (3) can be rewritten as

$$
\frac{V_{j, t}-V_{j, t-1}}{A_{j, t-1}}=-\dot{q}_{j, t}\left(\hat{g}_{j, t}-\widehat{\delta}_{j, t}\right)+\dot{q}_{j, t} \frac{A_{j, t}-A_{j, t-1}}{A_{j, t-1}}+\hat{r}_{j, t} \frac{V_{j, t-1}}{A_{j, t-1}}-\widehat{d}_{j, t} \frac{V_{j, t-1}}{A_{j, t-1}}
$$

which we estimate separately for each 3-digit SIC $i$ industry in each country $c$, using all firms with available accounting and market data in any given year, as follows:

$$
\frac{\Delta V_{j, t}^{i, c}}{A_{j, t-1}^{i, c}}=\beta_{0}^{i, c}+\beta_{1}^{i, c} \frac{\Delta A_{j, t}^{i, c}}{A_{j, t-1}^{i, c}}+\beta_{2}^{i, c} \frac{V_{j, t-1}^{i, c}}{A_{j, t-1}^{i, c}}+\beta_{3}^{i, c} \frac{\widehat{d}_{j, t}^{i} V_{j, t-1}^{i, c}}{A_{j, t-1}^{i, c}}+u_{j, t}^{i, c}
$$

The coefficient $\beta_{1}^{\mathrm{i}, \mathrm{c}}$, estimated across all publicly traded firms in a given industry $i$ and country c, represents the marginal Q for that industry in that country. We estimate the regression using ordinary least squares with rolling panels of 5 years to obtain yearly estimates of marginal $\mathrm{Q}\left(\dot{\hat{\mathrm{q}}}_{\mathrm{t}}^{\mathrm{i}, \mathrm{c}}\right)$. 
Estimates of $\dot{\hat{\mathrm{q}}}_{\mathrm{t}}^{\mathrm{i}, \mathrm{c}}$ are determined at the industry level, rather than firm level, for three main reasons. First, estimation at the firm-level would require many years of data, and could therefore suffer from severe survivorship bias. Second, as the production technology employed may change through time, estimates based on long-term event windows could be unreliable. Third, measuring across firms should reduce the impact of noise on our estimation. ${ }^{19}$ Mitigating noise is important as we use marginal Q estimated across publicly traded firms to proxy for the investment opportunities faced by (mostly) private firms.

We define $\mathrm{V}_{\mathrm{j}, \mathrm{t}}$ as $\left(C S_{j, t}+P S_{j, t}+L T D_{j, t}+S T D_{j, t}\right) / G D P$ deflator $_{t} . C S_{j, t}$ is the market value of outstanding common shares of firm $j$ at the end of year $t$ (Worldscope item WC08001). $P S_{j, t}$ is the value of preferred shares of firm $j$ at the end of year $t$ (Worldscope item WC03451). $L T D_{j, t}$ and $S T D_{j, t}$ are the book values of firm $j$ 's long-term and short-term debt, respectively (Worldscope items WC03251 and WC03051). GDP deflators are taken from the World Bank, World Development Indicators and from EconStats. ${ }^{20}$ We use them to convert values into 2000 prices.

We define $A_{j, t}$ as $\left(K_{j, t}+S T A_{j, t}\right) . K_{j, t}$ is the estimated market value of firm $j$ 's property, plant and equipment (PPE). We use a perpetual inventory formula to estimate the market value of PPE, using data for the previous 10 years. ${ }^{21}$ In particular, the estimated market value of PPE at the end of year $t$ is computed as:

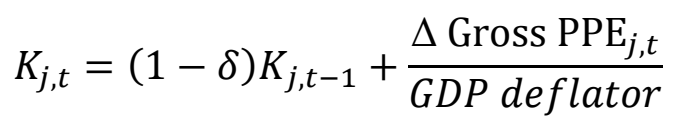

\footnotetext{
${ }^{19}$ All variables in the regression are winsorized at the top and bottom $1 \%$ to reduce the impact of outliers.

${ }^{20} \mathrm{http} / / /$ www.econstats.com/wdi/wdiv_758.htm.

${ }^{21}$ The first year of data we use in this calculation is 1983. If a company's history is shorter than 10 years, we use the first available data point for that firm.
} 
We set $K_{j, t-10}=\frac{\text { Net PPE }_{j, t-10}}{\text { GDP deflator }}$. Net PPE is gross property, plant and equipment, less accumulated reserves for depreciation, depletion and amortization (Worldscope item WC02501). We assume a constant annual depreciation rate, $\delta$, of $10 \%$. The change in gross PPE (Worldscope item WC02301) measures the annual spending in PPE. Therefore, the estimated market value of PPE at the end of year $t$ is equal to the estimated market value of PPE at the end of year $t-1$ minus $10 \%$ depreciation plus (deflated) capital spending during year $t$.

$S T A_{j, t}$ is the book value of firm $j$ 's short term assets (Worldscope item WC02201), expressed in 2000 prices. We do not attempt to estimate the market value of short term assets, as Worldscope does not provide information on the method used to evaluate inventories (e.g., LIFO vs. FIFO). Finally, we define $\widehat{\mathrm{d}}_{\mathrm{j}, \mathrm{t}}^{\mathrm{i}} \mathrm{V}_{\mathrm{j}, \mathrm{t}-1}^{\mathrm{i}}$ as dividends plus interest expense (Worldscope items WC04551 and WC01251). 


\section{References}

Adams, R.B., Funk, P.C., 2012. Beyond the glass ceiling: Does gender matter? Manage. Sci. 58, 219-235.

Adams, R.B., Ragunathan, V., 2013. Lehman sisters. University of New South Wales \& University of Queensland working paper.

Adams, R.B., Ferreira, D., 2009. Women in the boardroom and their impact on governance and performance. J.Financ.Econ. 94, 291-309.

Ahern, K.R., Dittmar, A., 2012. The changing of the boards: The impact on firm valuation of mandated female board representation. Q.J.Econ. 127, 137-197.

Akerlof, G.A., Kranton, R.E., 2000. Economics and identity, Q.J.Econ. 115, 715-753.

Altonji, J.G., Blank, R.M., 1999. Race and gender in the labor market. In Ashenfelter, Orley C. and David Card Eds., Handbook of Labor Economics, Vol. 3. Elsevier Publisher.

Arrow, K.J., 1984. The theory of risk aversion. In Individual Choice under Certainty and Uncertainty, collected papers of K.J. Arrow, pages 147-171. Harvard University Press, Cambridge, MA.

Bagehot, W., 1873. Lombard Street: A Description of the Money Market (1962 ed.) (Irwin, Homewood, IL).

Bandiera, O., Guiso, L., Prat, A., Sadun, R., 2015. Matching firms, managers and incentives. J. Lab. Econ. 33, 623-681.

Barber, B.M., Odean, T., 2001. Boys will be boys: Gender, overconfidence, and common stock investment. Q.J.Econ. 116, 261-292.

Beck, T., Levine, R., Loayza, N., 2000. Finance and the sources of growth. J.Financ.Econ. 58, 261-300.

Benmelech, E., Frydman, C., 2015. Military CEOs. J.Financ.Econ. 117, 43-59.

Berger, A.N., Kick, T., Schaeck, K., 2014. Executive board composition and bank risk taking. J.Corp.Finance 28, 48-65. 
Bernasek, A., Shwiff, S., 2001. Gender, risk, and retirement. Journal of Economic Issues 35, 345-356.

Bertrand, M., 2011. New perspectives on gender. In Orley Ashenfelter and David Card eds., Handbook of Labor Economics, Vol. 4B, 1543-1590.

Bertrand, M., Schoar, A., 2003. Managing with style: The effect of managers on firm policies. Q.J.Econ. 118, 1169-1208.

Bertrand, M., Goldin, C., Katz, L.F., 2010. Dynamics of the gender gap for young professionals in the financial and corporate sectors. Am. Econ. J. Appl. Econ. 2, 228-255.

Bond, S., Van Reenen, J., 2007. Microeconometric Models of Investment and Employment. Handbook of Econometrics. In: Heckman, J.J., Leamer, E.E. (Eds.), Handbook of Econometrics, vol. 6A. North Holland, Amsterdam, 4417-4498.

Booth, A.L., Nolen, P., 2012. Gender differences in risk behaviour: does nurture matter? Econ. J. 122, F56-F78.

Bröder, A., Hohmann, N., 2003. Variations in risk taking behavior over the menstrual cycle: an improved replication. Evol. Hum. Behav. 24, 391-398.

Bruce, A.C., Johnson, J.E.V., 1994, Male and female betting behaviour: New perspectives. J. Gambl. Stud. 10, 183-198.

Bugeja, M,. Matolcsy, Z.P., Spiropoulos, H., 2012. Is there a gender gap in CEO compensation? J.Corp.Finance 18, 849-859.

Cain, M.D., McKeon, S.B., 2014. CEO personal risk-taking and corporate policies. J.Financ.Quant.Anal., forthcoming.

Calvet, L.E., Sodini, P., 2014. Twin picks: Disentangling the determinants of risk-taking in household portfolios. J.Financ. 69, 867-906.

Cole, R., 2013. What do we know about the capital structure of privately held US firms? Evidence from the surveys of small business finance. Financ. Manag. 42, 777-813. 
Cronqvist, H., Makhija, A.K., Yonker, S.E., 2012. Behavioral consistency in corporate finance: CEO personal and corporate leverage. J.Financ.Econ. 103, 20-40.

Croson, R., Gneezy, U., 2009. Gender differences in preferences. J. Econ. Lit. 47, 448-474.

Durnev, A., Morck, R., Yeung, B., 2004. Value-enhancing capital budgeting and firm-specific stock return variation. J.Financ. 59, 65-105.

Edwards, D.A., O'Neal, J.L., 2009. Oral contraceptives decrease saliva testosterone but do not affect the rise in testosterone associated with athletic competition. Horm. Behav. 56, 195198.

Faccio, M., Marchica, M.-T., Mura, R., 2011. Large shareholder diversification and corporate risk-taking. Rev.Financ.Stud. 24, 3601-3641.

Farrell, K.A.,. Hersch, P.L., 2005. Additions to corporate boards: the effect of gender. J.Corp.Finance 11, 85-106.

Fazzari, S.M.,. Hubbard, G.R.,. Petersen, B.C., 1988. Financing constraints and corporate investment. Brookings Pap. Econ. Ac. 1, 141-195.

Forbes, D.P., 2005. Are some entrepreneurs more overconfident than others? J.Bus. Venturing 20, 623-640.

Geiler, P., Renneboog, L., 2015. Are female top managers really paid less? J.Corp.Finance 35, 345-369.

Goldin, C., 1990. Understanding the gender gap: An economic history of American women. New York: Oxford University Press.

Goldin, C., Katz, L., 2010. The career cost of family, The Sloan Foundation working paper.

Greenwood, J., Jovanovic, B., 1990. Financial development, growth, and the distribution of income. J. Polit. Economy, 1076-1107.

Grinblatt, M., Keloharju, M., 2001. How distance, language, and culture influence stockholdings and trades. J.Financ. 56, 1053-1073. 
Guiso, L., Monte, F., Sapienza, P., Zingales, L., 2008. Culture, gender and math. Science 320, 1164-1165.

Heckman, J.J., 1979. Sample selection as a specification error. Econometrica 47, 153-161.

Huang, J.,. Kisgen, D.J., 2013. Gender and Corporate Finance: Are Male Executives Overconfident Relative to Female Executives? J.Financ.Econ. 108, 822-839.

Hubbard, G.R., 1998. Capital market imperfections and investment. J. Econ. Lit. 36, 193-227.

Huberman, G., 2001. Familiarity breeds investment. Rev.Financ.Stud. 14, 659-680.

Hudgens, G.A., Fatkin, L.T., 1985. Sex differences in risk taking: Repeated sessions on a computersimulated task. J. Psychol. 119, 197-206.

John, K., Litov, L., Yeung, B., 2008. Corporate governance and risk-taking. J.Financ. 63, 16791728.

Johnson, J.E.V., Powell, P.L., 1994. Decision making, risk and gender: Are managers different? Brit. J. Manage. 5, 123-138.

Klapper, L., Laeven, L., Rajan, R., 2006. Entry regulation as a barrier to entrepreneurship. J.Financ.Econ. 82, 591-629.

Kovalchik, S., Camerer, C.F.,. Grether, D.M., Plott, C.R., Allman, J.M., 2005. Aging and decision making: a comparison between neurologically healthy elderly and young individuals. J. Econ. Behav. Organ. 58, 79-94.

Levi, M., Li, K., Zhang, F., 2010. Deal or No Deal: Hormones and the Mergers and Acquisitions Game. Manage. Sci. 56, 1462-1483

Levi, M., Li, K., Zhang, F., 2014. Director Gender and Mergers and Acquisitions. J.Corp.Finance 28, 185-200.

Lundeberg, M.A., Fox, P.W., Punćochaŕ, J., 1994. Highly confident but wrong: Gender differences and similarities in confidence judgments. J. Educ. Psychol. 86, 114-121. 
Maestripieri, D., Sapienza, P., Zingales, L., 2009. Gender Differences in Financial Risk Aversion and Career Choices are Affected by Testosterone. P. Natl. Acad. Sci. USA 106, 1526815273.

Malmendier, U., Tate, G., 2005. CEO overconfidence and corporate investment. J.Financ. 60, 2661-2700.

Malmendier, U., Tate, G., 2008. Who makes acquisitions? CEO overconfidence and the market's reaction. J.Financ.Econ. 89, 20-43.

Malmendier, U., Tate, G., Yan, J., 2011. Overconfidence and early-life experiences: The effect of managerial traits on corporate financial policies. J.Financ. 66, 1687-1733.

Manning, A., Saidi, F., 2010. Understanding the gender pay gap: What's competition got to do with it? Ind. Lab. Relat. Rev. 63, 681-698.

Matsa, D.A., Miller, A.R., 2013. A female style in corporate leadership? Evidence from quotas. Am. Econ. J. Appl. Econ. 5, 136-169.

McLean, R. D., Zhang, T., Zhao, M., 2012. Why does the law matter? Investor protection and its effects on investment, finance, and growth. J.Financ. 67, 313-350.

Morck, R.M. Yavuz, D., Yeung, B., 2011. Banking system control, capital allocation, and economy performance. J.Financ.Econ. 100, 264-283.

Paravisini, D., Rappoport, V., Ravina, E., 2015. Risk aversion and wealth: Evidence from person-to-person lending portfolios. Manage. Sci., forthcoming.

Popov, A., Roosenboom, P., 2009. On the real effects of private equity investments: Evidence from new business creation. European Central Bank working paper No. 1078.

Rosenbaum, P.R., Rubin, D.B. 1983. The central role of the propensity score in observational studies for causal effects. Biometrika 70, 41-55.

Seasholes, M.S., Zhu, N., 2010. Individual investors and local bias. J.Financ. 65, 1987-2010.

Sila, V., Gonzalez, A., Hagendorff, J., 2016. Women on board: Does boardroom gender diversity affect firm risk? J.Corp.Finance 36, 26-53. 
Sundén, A.E., Surette, B.J., 1998. Gender differences in the allocation of assets in retirement savings plans. Am. Econ. Rev. 88, 207-211.

Taylor, R.N., 1975. Age and experience as determinants of managerial information processing and decision making performance. Acad. Manage. J. 18, 74-81.

Weber, A., Zulehner, C., 2010. Female hires and the success of start-up firms. Am. Econ. Rev. 100, 358-361.

Wurgler, J., 2000. Financial markets and the allocation of capital. J.Financ.Econ. 58, 187-214. 


\section{Table 1}

Univariate statistics

Leverage is defined as the ratio of financial debt divided by the sum of financial debt plus equity. Financial debt is the sum of long term debt (excluding "other non-current liabilities") plus short term loans. $\sigma(R O A)$ is the volatility of the firm's operating return on assets (ROA), defined as the ratio of earnings before interests and taxes to total assets. Likelihood of survival is an indicator variable that takes the value of 1 if the firm survives at least 5 years, and 0 otherwise. Female CEO is an indicator variable that takes the value of 1 if the CEO is a woman, and 0 otherwise. CEO ownership is the cash flow rights of the CEO on the firm's earnings. Ln (CEO wealth) is the natural logarithm of the CEO's equity wealth. To determine equity wealth for each CEO, we approximate the dollar value of the investment in each firm in which he/she appears as a shareholder by multiplying the individual's ownership in the firm by the firm's book value of equity. We then sum the value of all equity investments across firms to obtain the CEO's total equity wealth. Ln (CEO age) is the natural logarithm of the CEO's age. Cash flow rights is the ownership rights of the largest ultimate shareholder. Sales growth is calculated as the annual rate of growth of sales. Ln (Size) is the natural log of total assets (in thousands US\$), expressed in 2000 prices. Total assets is the sum of total fixed assets (tangible and intangible fixed assets and other fixed assets) and current assets (inventory, receivables, and other current assets). Ln (1+Age) is the natural logarithm of (1 + the number of years since incorporation). Tangibility is calculated as the ratio of fixed to total assets. Private firm is an indicator denoting firms that are not publicly traded. $\triangle$ gross PPE/Total fixed assets is the ratio of capital expenditure relative to the capital stock. Capital expenditures are computed as the annual change in (net) total fixed assets plus depreciation. Value added growth is computed as the difference between the natural log of value added in year $\mathrm{t}$ and the natural log of value added in year $\mathrm{t}-1$. Value added, in constant US dollars (year 2000 prices), is defined as earnings before interest and taxes plus cost of employees. Marginal $Q$ measures the change in the market value of firm associated with an (unexpected) change in capital investment. It is estimated by industry, country, and year. Cash flow/Total fixed assets is net income plus depreciation, divided by total fixed assets. With the exception of Likelihood of survival, all statistics are computed for the panel of observations. Likelihood of survival can only be computed cross-sectionally.

\begin{tabular}{|c|c|c|c|c|c|c|}
\hline \multirow[b]{2}{*}{ Full sample } & \multicolumn{3}{|c|}{ Full sample } & \multirow{2}{*}{$\begin{array}{r}\text { Female } \\
\text { CEOs }\end{array}$} & \multirow{2}{*}{$\begin{array}{r}\text { Male } \\
\text { CEOs }\end{array}$} & \multirow{2}{*}{$\begin{array}{c}\text { p-value } \\
\text { of diff. }\end{array}$} \\
\hline & Mean & Median & Stnd. dev. & & & \\
\hline Leverage & 0.374 & 0.329 & 0.326 & 0.324 & 0.379 & 0.000 \\
\hline$\sigma(\mathrm{ROA})$ & 0.048 & 0.030 & 0.057 & 0.027 & 0.050 & 0.000 \\
\hline Likelihood of survival & 0.517 & 1 & 0.500 & 0.614 & 0.505 & 0.000 \\
\hline Female CEO & 0.094 & 0 & 0.292 & & & \\
\hline CEO ownership & 0.044 & 0 & 0.167 & 0.060 & 0.043 & 0.000 \\
\hline Ln(CEO wealth) & 7.525 & 7.583 & 1.922 & 7.486 & 7.529 & 0.079 \\
\hline Ln(CEO age) & 3.919 & 3.932 & 0.190 & 3.902 & 3.921 & 0.000 \\
\hline Cash flow rights & 0.638 & 0.680 & 0.358 & 0.576 & 0.644 & 0.000 \\
\hline ROA & 0.059 & 0.049 & 0.108 & 0.065 & 0.058 & 0.000 \\
\hline Sales growth & 0.217 & 0.050 & 0.834 & 0.184 & 0.221 & 0.000 \\
\hline Ln (Size) & 10.313 & 10.132 & 1.400 & 10.127 & 10.332 & 0.000 \\
\hline Ln (1+Age) & 2.906 & 2.944 & 0.809 & 2.929 & 2.904 & 0.000 \\
\hline
\end{tabular}




\begin{tabular}{lcccccc} 
Tangibility & 0.212 & 0.129 & 0.233 & 0.209 & 0.213 & 0.063 \\
Private firm & 0.954 & 1 & 0.210 & 0.969 & 0.952 & 0.000 \\
Agross PPE/Total fixed assets & 0.353 & 0.167 & 0.864 & 0.370 & 0.351 & 0.029 \\
Value added growth & 0.088 & 0.055 & 0.396 & 0.089 & 0.088 & 0.204 \\
Marginal Q & 1.123 & 0.948 & 1.152 & 0.862 & 1.149 & 0.000 \\
Cash flow / Total fixed assets & 1.129 & 0.273 & 4.012 & 1.113 & 1.131 & 0.135 \\
\hline
\end{tabular}




\section{Table 2}

Female CEOs and corporate risk-taking

In regression (1) the dependent variable is Leverage, defined as the ratio of financial debt divided by the sum of financial debt plus equity; in regression (2) the dependent variable is the volatility of the firm's operating return on assets $\sigma(R O A) \mathrm{x} 100$, where ROA is defined as the ratio of earnings before interest and taxes to total assets; in regression (3) the dependent variable is an indicator denoting whether the firm survived over a 5-year period. Regressions (1) and (2) are run for the panel of observations. Regression (3) can only be run cross-sectionally. Female $C E O$ is an indicator variable that takes the value of 1 if the CEO is a woman, and 0 otherwise. Control variables are defined in Table 1. P-values, adjusted for heteroskedasticity and clustering at the firm level (in the panel regressions), are reported in brackets below the coefficients.

\begin{tabular}{|c|c|c|c|}
\hline & $\begin{array}{c}\text { (1) } \\
\text { Leverage }\end{array}$ & $\begin{array}{c}(2) \\
\sigma(\mathrm{ROA}) \times 100\end{array}$ & $\begin{array}{c}\text { (3) } \\
\text { Likelihood of } \\
\text { survival }\end{array}$ \\
\hline Female CEO & $\begin{array}{c}-0.034 * * * \\
{[0.000]}\end{array}$ & $\begin{array}{c}-1.998 * * * \\
{[0.000]}\end{array}$ & $\begin{array}{c}0.253^{* * *} \\
{[0.000]}\end{array}$ \\
\hline CEO ownership & $\begin{array}{c}0.095^{* * *} \\
{[0.000]}\end{array}$ & $\begin{array}{c}-0.910 * * * \\
{[0.000]}\end{array}$ & $\begin{array}{c}-0.212 * * * \\
{[0.000]}\end{array}$ \\
\hline Cash flow rights & $\begin{array}{c}-0.001 \\
{[0.714]}\end{array}$ & $\begin{array}{c}0.654 * * * \\
{[0.000]}\end{array}$ & $\begin{array}{c}0.051 * * * \\
{[0.005]}\end{array}$ \\
\hline Leverage & & $\begin{array}{c}-0.447 * * * \\
{[0.000]}\end{array}$ & $\begin{array}{c}-0.057 * * * \\
{[0.001]}\end{array}$ \\
\hline ROA & $\begin{array}{c}-0.626 * * * \\
{[0.000]}\end{array}$ & $\begin{array}{c}-3.525 * * * \\
{[0.000]}\end{array}$ & $\begin{array}{c}0.891^{* * *} \\
{[0.000]}\end{array}$ \\
\hline Sales growth & $\begin{array}{c}0.009 * * * \\
{[0.000]}\end{array}$ & $\begin{array}{c}-0.045^{* *} \\
{[0.029]}\end{array}$ & $\begin{array}{c}-0.021 * * * \\
{[0.000]}\end{array}$ \\
\hline Ln (Size) & $\begin{array}{c}0.013 * * * \\
{[0.000]}\end{array}$ & $\begin{array}{c}-0.144 * * * \\
{[0.000]}\end{array}$ & $\begin{array}{c}0.166^{* * *} \\
{[0.000]}\end{array}$ \\
\hline Ln (1+Age) & $\begin{array}{c}-0.042 * * * \\
{[0.000]}\end{array}$ & $\begin{array}{c}-0.423 * * * \\
{[0.000]}\end{array}$ & $\begin{array}{c}0.102 * * * \\
{[0.000]}\end{array}$ \\
\hline Tangibility & $\begin{array}{c}0.174 * * * \\
{[0.000]}\end{array}$ & $\begin{array}{c}-1.116 * * * \\
{[0.000]}\end{array}$ & $\begin{array}{c}0.163^{* * *} \\
{[0.000]}\end{array}$ \\
\hline Private firm & $\begin{array}{c}0.095 * * * \\
{[0.000]}\end{array}$ & $\begin{array}{c}-0.858 * * * \\
{[0.000]}\end{array}$ & $\begin{array}{c}-0.365 * * * \\
{[0.000]}\end{array}$ \\
\hline Country fixed effects & Yes & Yes & Yes \\
\hline Industry fixed effects & Yes & Yes & Yes \\
\hline Year fixed effects & Yes & Yes & Yes \\
\hline R-squared & 0.184 & 0.101 & 0.132 \\
\hline $\begin{array}{l}\text { No. of observations } \\
\text { No. of firms }\end{array}$ & $\begin{array}{l}338,397 \\
132,590\end{array}$ & $\begin{array}{c}113,614 \\
47,208\end{array}$ & 67,089 \\
\hline
\end{tabular}




\section{Table 3}

Propensity score matching estimators

In this table, we identify a control sample of firms that are run by male CEOs by employing a propensity score matching procedure. The propensity score is estimated within a country-industry-year-public/private status category, using all firm characteristics included in our regression analyses. We require that the difference between the propensity score of the firm run by a Female CEO and its matching peer does not exceed $0.1 \%$ in absolute value. We then compare the levels of Leverage, $\sigma(R O A)$ x100 and the likelihood of survival between the two groups. Leverage is defined as the ratio of financial debt divided by the sum of financial debt plus equity. Financial debt is the sum of long term debt (excluding "other non-current liabilities") plus short term loans; the volatility of the firm's operating return on assets is $\sigma(R O A) \times 100$, where ROA is defined as the ratio of earnings before interest and taxes to total assets; the Likelihood of survival is an indicator denoting whether the firm survived over a 5-year period.

Panel A: The propensity score is estimated within a country-industry-year-public/private status category using available firm-level observables.

\begin{tabular}{|c|c|c|c|c|}
\hline & $\begin{array}{c}\text { No. of } \\
\text { observations }\end{array}$ & Mean & $\begin{array}{c}\text { Difference } \\
\text { (Female CEOs - } \\
\text { Male CEOs) }\end{array}$ & $\begin{array}{l}\text { P-value } \\
\text { of diff. }\end{array}$ \\
\hline $\begin{array}{l}\text { Leverage (Female CEOs) } \\
\text { Leverage (Male CEOs) }\end{array}$ & 21,848 & $\begin{array}{l}0.331 \\
0.362\end{array}$ & -0.031 & 0.000 \\
\hline $\begin{array}{l}\sigma(\mathrm{ROA}) \times 100 \text { (Female CEOs) } \\
\sigma(\mathrm{ROA}) \times 100 \text { (Male CEOs) }\end{array}$ & 6,566 & $\begin{array}{l}2.580 \\
4.083\end{array}$ & -1.503 & 0.000 \\
\hline $\begin{array}{l}\text { Likelihood of survival (Female CEOs) } \\
\text { Likelihood of survival (Male CEOs) }\end{array}$ & 3,617 & $\begin{array}{l}0.662 \\
0.563\end{array}$ & 0.099 & 0.000 \\
\hline
\end{tabular}

Panel B: The propensity score is estimated within a country-industry-year-public/private status category using available firm-level observables as well as CEO wealth and CEO age.

\begin{tabular}{lcccc}
\hline & $\begin{array}{c}\text { No. of } \\
\text { observations }\end{array}$ & $\begin{array}{c}\text { Mean } \\
\text { (Female CEOs - } \\
\text { Male CEOs) }\end{array}$ & $\begin{array}{c}\text { P-value } \\
\text { of diff. }\end{array}$ \\
\hline $\begin{array}{l}\text { Leverage (Female CEOs) } \\
\text { Leverage (Male CEOs) }\end{array}$ & 1,129 & $\begin{array}{l}0.467 \\
0.489\end{array}$ & -0.022 & 0.074 \\
$\begin{array}{l}\text { (ROA) x 100 (Female CEOs) } \\
\text { (ROA) x 100 (Male CEOs) }\end{array}$ & 220 & 2.074 & -0.594 & 0.002 \\
& & 2.668 & & \\
Likelihood of survival (Female CEOs) & 43 & 0.790 & 0.16 & 0.228 \\
Likelihood of survival (Male CEOs) & & 0.674 & & \\
\hline
\end{tabular}




\section{Table 4}

Female CEOs and corporate risk-taking

This table reports panel regression results with firm fixed effects. In regressions (1) and (3), the dependent variable is Leverage, defined as the ratio of financial debt divided by the sum of financial debt plus equity. In regressions (2) and (4), the dependent variable is the volatility of the firm's operating return on assets $\sigma(R O A) \mathrm{x} 100$, where ROA is defined as the ratio of earnings before interest and taxes to total assets. Female CEO is an indicator variable that takes the value of 1 if the CEO is a woman and 0 otherwise. Control variables are defined in Table 1. P-values, adjusted for heteroskedasticity and clustering at the firm level, are reported in brackets below the coefficients. In this analysis, we include only firms that experience a change from a male CEO to a female CEO or vice versa, as only those firms contribute to the identification.

\begin{tabular}{lcccc}
\hline & $(1)$ & $(2)$ & $(3)$ & $(4)$ \\
& Leverage & $\sigma(\mathrm{ROA}) \mathrm{x} 100$ & Leverage & $\sigma(\mathrm{ROA}) \mathrm{x} 100$ \\
\hline Female CEO & $-0.028^{* * *}$ & $-1.584^{* * *}$ & $-0.020^{*}$ & $-0.876^{* * *}$ \\
& {$[0.000]$} & {$[0.000]$} & {$[0.096]$} & {$[0.007]$} \\
CEO ownership & -0.013 & 0.271 & $0.057^{*}$ & -0.842 \\
& {$[0.200]$} & {$[0.586]$} & {$[0.094]$} & {$[0.509]$} \\
Cash flow rights & 0.01 & -0.189 & 0.052 & 0.528 \\
& {$[0.132]$} & {$[0.642]$} & {$[0.379]$} & {$[0.696]$} \\
Leverage & & 0.603 & & 1.287 \\
& & {$[0.103]$} & & {$[0.264]$} \\
ROA & $-0.376^{* * *}$ & $-3.640^{* *}$ & $-0.527^{* * *}$ & -5.127 \\
& {$[0.000]$} & {$[0.017]$} & {$[0.000]$} & {$[0.323]$} \\
Sales growth & $0.006^{* * *}$ & 0.059 & $0.011^{*}$ & -0.178 \\
& {$[0.000]$} & {$[0.309]$} & {$[0.059]$} & {$[0.611]$} \\
Ln (Size) & $0.040^{* * *}$ & -0.329 & $0.127^{* * *}$ & -1.1 \\
& {$[0.000]$} & {$[0.210]$} & {$[0.000]$} & {$[0.484]$} \\
Ln (1+Age) & $-0.046^{* * *}$ & $1.501^{*}$ & 0.076 & 3.557 \\
Tangibility & {$[0.004]$} & {$[0.089]$} & {$[0.261]$} & {$[0.401]$} \\
& $0.111^{* * *}$ & $-2.735^{* *}$ & $0.142^{* *}$ & -1.822 \\
Private firm & {$[0.000]$} & {$[0.015]$} & {$[0.036]$} & {$[0.407]$} \\
& 0.013 & 0.602 & 0.061 & 3.803 \\
Ln (CEO wealth) & {$[0.303]$} & {$[0.586]$} & {$[0.390]$} & {$[0.353]$} \\
& & & $-0.045^{* * *}$ & -0.008 \\
Ln (CEO age) & & & {$[0.000]$} & {$[0.968]$} \\
& & & $0.093^{* *}$ & -0.24 \\
Firm fixed effects & & & {$[0.047]$} & {$[0.864]$} \\
Year fixed effects & Yes & Yes & Yes & Yes \\
R-squared & 0.724 & 0.421 & 0.83 & 0.553 \\
No. of observations & 46,513 & 22,879 & 2,926 & 1,473 \\
No. of firms & 11,150 & 8,213 & 1,124 & 623 \\
\hline
\end{tabular}




\section{Table 5}

Propensity score matching estimators for transition firms

In this table, we identify control samples of firms that are always run by male CEOs by employing a propensity score matching procedure. The propensity score is estimated within a country-industry-year-public/private status category, as a function of ROA, sales growth, the natural log of total assets, the natural log of firm age, asset tangibility, the ownership of the largest ultimate shareholder, and the ownership of the CEO. The treatment group in this Table includes firms experiencing a transition from male to female CEOs. We require that the difference between the propensity score of the firm run by a female CEO and its matching peer does not exceed $0.1 \%$ in absolute value. Leverage is defined as the ratio of financial debt divided by the sum of financial debt plus equity. Financial debt is the sum of long-term debt (excluding "other non-current liabilities") plus short-term loans; the volatility of the firm's operating return on assets is $\sigma(R O A) \times 100$, where ROA is defined as the ratio of earnings before interest and taxes to total assets.

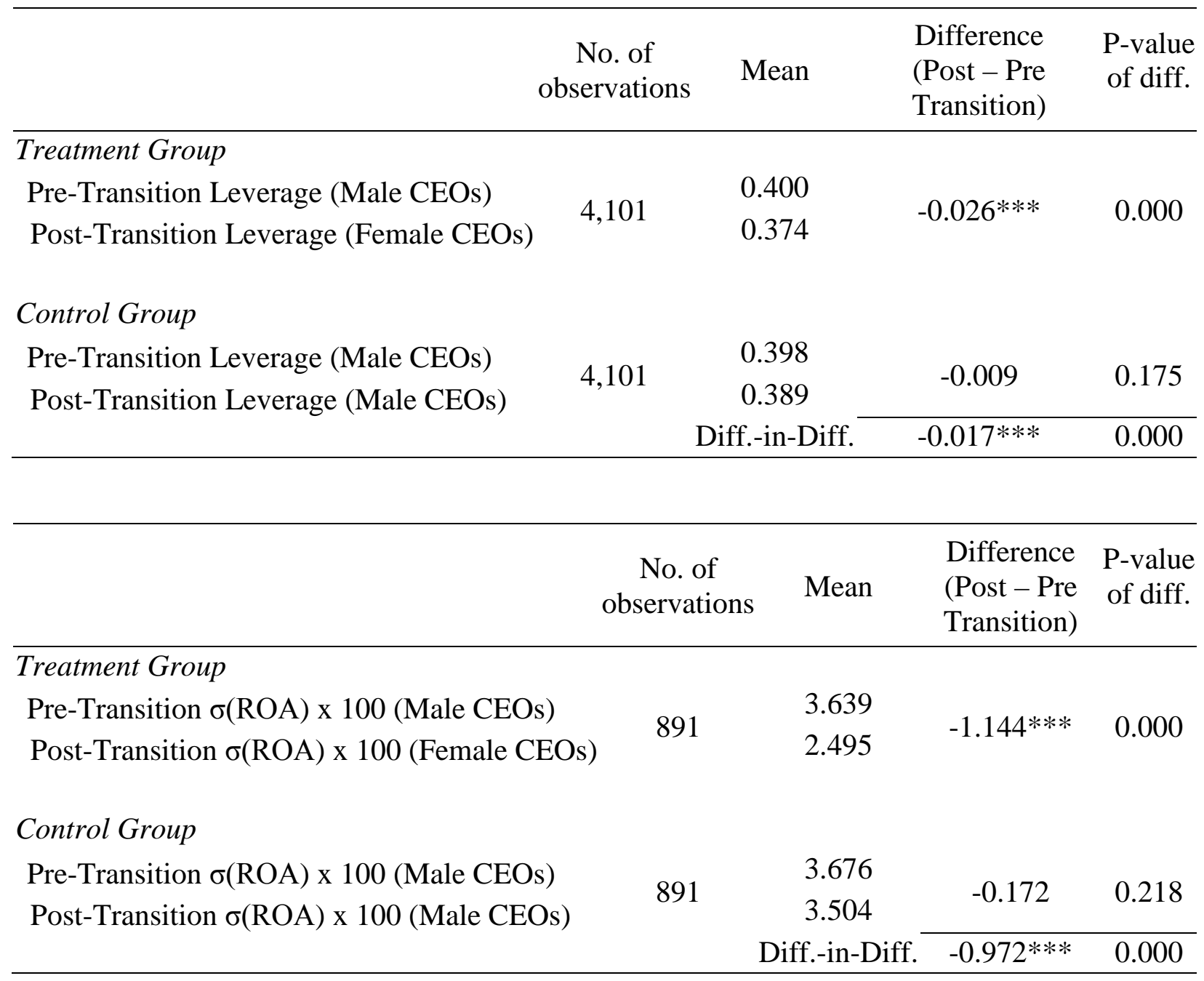




\section{Table 6 \\ Treatment effects}

In the second stage regressions, in regression (1) the dependent variable is Leverage, defined as the ratio of financial debt divided by the sum of financial debt plus equity; in regression (2) the dependent variable is the volatility of the firm's operating return on assets $\sigma(R O A) \mathrm{x} 100$, where ROA is defined as the ratio of earnings before interests and taxes to total assets; in regression (3) the dependent variable is an indicator denoting whether the firm survived over a 5-year period. In the first stage regressions we use the fraction, among all other firms in which the firm's male directors also serve as directors, of firms with (1) a female CEO, (2) above-average leverage, (3) above-average volatility of ROA in the subsequent five years and (4) lack of survival during the following five years as an exogenous determinant of the CEO gender selection choice. Control variables are defined in Table 1. The Inverse Mills ratio is calculated from the predicted values of the first stage probit regressions. P-values, adjusted for heteroskedasticity and clustering at the firm level are reported in brackets below the coefficients.

\section{Panel A: Second stage regressions}

(1)

\begin{tabular}{|c|c|c|c|}
\hline Dependent variable: & Leverage & $\sigma(\mathrm{ROA}) \times 100$ & $\begin{array}{c}\text { Likelihood of } \\
\text { survival }\end{array}$ \\
\hline \multirow[t]{2}{*}{ Female CEO } & $-0.070 * * *$ & $-2.746 * * *$ & $0.268 * *$ \\
\hline & {$[0.000]$} & {$[0.000]$} & [0.015] \\
\hline \multirow[t]{2}{*}{ CEO ownership } & $-0.014 * *$ & 0.006 & $-0.169 * * *$ \\
\hline & {$[0.015]$} & [0.984] & [0.000] \\
\hline \multirow[t]{2}{*}{ Cash flow rights } & $0.014 * * *$ & -0.198 & $0.061 * * *$ \\
\hline & {$[0.000]$} & [0.295] & [0.008] \\
\hline \multirow[t]{2}{*}{ Leverage } & & -0.054 & 0.041 \\
\hline & & [0.773] & [0.128] \\
\hline \multirow[t]{2}{*}{ ROA } & $-0.419 * * *$ & $-4.149 * * *$ & $0.835^{* * *}$ \\
\hline & {$[0.000]$} & {$[0.000]$} & {$[0.000]$} \\
\hline \multirow[t]{2}{*}{ Sales growth } & $0.006 * * *$ & 0.03 & $-0.012 * *$ \\
\hline & {$[0.000]$} & [0.256] & {$[0.014]$} \\
\hline \multirow[t]{2}{*}{ Ln (Size) } & $0.041^{* * *}$ & $-0.262 * *$ & $0.143 * * *$ \\
\hline & {$[0.000]$} & [0.039] & [0.000] \\
\hline \multirow[t]{2}{*}{ Ln (1+Age) } & $-0.045 * * *$ & $1.223 * * *$ & $0.123 * * *$ \\
\hline & {$[0.000]$} & {$[0.003]$} & {$[0.000]$} \\
\hline \multirow[t]{2}{*}{ Tangibility } & $0.133^{* * *}$ & $-1.816^{* * *}$ & $0.154^{* * *}$ \\
\hline & {$[0.000]$} & {$[0.000]$} & [0.000] \\
\hline \multirow[t]{2}{*}{ Private firm } & 0.006 & $1.562^{* * *}$ & $-0.428 * * *$ \\
\hline & [0.185] & {$[0.001]$} & [0.000] \\
\hline \multirow[t]{2}{*}{ Inverse Mills ratio } & $0.018^{* *}$ & $0.430^{*}$ & 0.063 \\
\hline & {$[0.014]$} & {$[0.096]$} & [0.289] \\
\hline Country Fixed Effects & Yes & Yes & Yes \\
\hline Industry Fixed Effects & Yes & Yes & Yes \\
\hline Year Fixed Effects & Yes & Yes & Yes \\
\hline
\end{tabular}


No. of observations

223,710

79,809

43,805

No. of firms

96,020

36,111

43,805

Panel B: First stage Probit model

(1)

(2)

(3)

Dependent variable:

Female CEO

Fraction of firms with a female CEO and

$1.509 * * *$

$1.551^{* * *}$

$1.724 * * *$

high risk-taking among other firms

in which male directors serve

\begin{tabular}{lccc} 
& {$[0.000]$} & {$[0.000]$} & {$[0.000]$} \\
Control variables & Yes & Yes & Yes \\
\hline Country Fixed Effects & Yes & Yes & Yes \\
Industry Fixed Effects & Yes & Yes & Yes \\
Year Fixed Effects & Yes & Yes & Yes \\
No. of observations & 223,710 & 79,809 & 43,805 \\
No. of firms & 96,020 & 36,111 & 43,805 \\
\hline
\end{tabular}




\section{Table 7}

\section{Female CEOs and the efficiency of capital allocation}

This table reports OLS regression results. In both Panels, the dependent variable is the ratio of capital expenditure relative to the capital stock. Capital expenditures are computed as the annual change in (net) total fixed assets plus depreciation. The capital stock is defined as the sum of tangible fixed assets plus intangible fixed assets plus other fixed assets. Value added growth is computed as the difference between the natural $\log$ of value added in year $t$ and the natural log of value added in year $t-1$. Value added, in constant US dollars (year 2000 prices), is defined as earnings before interest and taxes plus cost of employees. Marginal $Q$ measures the change in the market value of a firm associated with an (unexpected) change in capital investment. It is estimated by industry, country, and year. Cash flow/Total fixed assets is net income plus depreciation, divided by total fixed assets. Ln (1+Age) is the natural logarithm of $(1+$ the number of years since incorporation). Female CEO is an indicator variable that takes the value of 1 if the CEO is a woman, and 0 otherwise. The Inverse Mills ratio is calculated from the predicted values of the first stage probit regressions. Risk-avoidance is an index constructed by adding 1 when (1) a firm's leverage is in the bottom $20 \%$ of the distribution; (2) the volatility of firm-level profitability is in the bottom $20 \%$ of the distribution; and (3) if the firm survives at least 5 years. The index ranges from 0 to 3, with higher scores denoting greater risk-avoidance. In Panel A, p-values are adjusted for heteroskedasticity and clustering at the firm level. In Panel B, bootstrapped p-values are reported in brackets below the coefficients (except for model 2).

Panel A: Growth-model of investment

\begin{tabular}{lccc}
\hline & $(1)$ & $(2)$ & $(3)$ \\
\hline Value added growth & $0.154^{* * *}$ & $0.176^{* * *}$ & $0.150^{* * *}$ \\
& {$[0.000]$} & {$[0.000]$} & {$[0.000]$} \\
Cash flow / Total fixed assets & $0.085^{* * *}$ & $0.083^{* * *}$ & $0.103^{* * *}$ \\
& {$[0.000]$} & {$[0.000]$} & {$[0.000]$} \\
Ln (1+Age) & $-0.190^{* * *}$ & $-0.193^{* * *}$ & $-0.287^{* * *}$ \\
& {$[0.000]$} & {$[0.000]$} & {$[0.000]$} \\
Female CEO & 0.011 & -0.096 & -0.025 \\
& {$[0.298]$} & {$[0.363]$} & {$[0.212]$} \\
Female CEO * Value added growth & $-0.073^{* * *}$ & $-0.092^{* *}$ & -0.073 \\
& {$[0.009]$} & {$[0.020]$} & {$[0.227]$} \\
Inverse Mills ratio & & 0.048 & \\
& & {$[0.352]$} & \\
Risk-avoidance & & & $-0.023^{*}$ \\
& & & {$[0.050]$} \\
Risk-avoidance * Value added growth & & & -0.001 \\
& & & {$[0.362]$} \\
\hline Firm fixed effects & Yes & Yes & Yes \\
Year fixed effects & Yes & Yes & Yes \\
R-squared & 0.097 & 0.098 & 0.099 \\
No. of observations & 173,111 & 118,135 & 49,645 \\
No. of firms & 75,876 & 55,330 & 22,776 \\
\hline
\end{tabular}




\section{Table 7}

Female CEOs and the efficiency of capital allocation (Cont'd)

Panel B: Q-model of investment

\begin{tabular}{lccc}
\hline & $(1)$ & $(2)$ & $(3)$ \\
\hline Marginal Q & $0.013^{* * *}$ & $0.013^{* * *}$ & $0.008^{* *}$ \\
& {$[0.000]$} & {$[0.000]$} & {$[0.031]$} \\
Cash flow / Total fixed assets & $0.053^{* * *}$ & $0.052^{* * *}$ & $0.061^{* * *}$ \\
& {$[0.000]$} & {$[0.000]$} & {$[0.000]$} \\
Ln (1+Age) & $-0.042^{* * *}$ & $-0.037^{* * *}$ & $-0.040^{* * *}$ \\
& {$[0.000]$} & {$[0.000]$} & {$[0.000]$} \\
Female CEO & $0.015^{*}$ & $-0.229^{* * *}$ & 0.006 \\
& {$[0.073]$} & {$[0.007]$} & {$[0.815]$} \\
Female CEO * Marginal Q & $-0.020^{* * *}$ & $-0.040^{* * *}$ & -0.007 \\
& {$[0.000]$} & {$[0.000]$} & {$[0.464]$} \\
Inverse Mills ratio & & $0.124^{* * *}$ & \\
& & {$[0.004]$} & \\
Risk-avoidance & & & $-0.013^{* *}$ \\
& & & {$[0.048]$} \\
Risk-avoidance * Marginal Q & & & $-0.030^{*}$ \\
& & & {$[0.067]$} \\
\hline Country fixed effects & Yes & Yes & Yes \\
Industry fixed effects & Yes & Yes & Yes \\
Year fixed effects & Yes & Yes & Yes \\
R-squared & 0.081 & 0.075 & 0.089 \\
No. of observations & 174,111 & 120,571 & 47,376 \\
No. of firms & 77,785 & 57,076 & 22,427 \\
\hline
\end{tabular}

